\title{
Additions and changes to
}

\section{Genre Terms: A Thesaurus}

\author{
Prepared by the RBMS Standards Committee
}

John B. Thomas III, Chair

\section{An update on the types of materials found in rare book libraries.}

G and Special Collections Cataloguing was prepared by the Standards Committee of the Rare Books and Manuscripts Section of ACRL, and was published by ACRL in 1983. Since then, it has earned wide acceptance as a means of providing standardized access to the intellectual genres of textual materials in rare book libraries.

The following list of additions and changes has been approved by the RBMS Standards Committee and serves as a supplement to the published thesaurus. The twelve terms preceded by asterisks $\left({ }^{*}\right)$ are new to the list and are followed by their full note and reference structure. All other terms appear due to additions or changes to notes or references; it should be noted that for these terms only those elements which are new or changed appear here.

The Introduction to Genre Terms provides a full explanation of the scope of the thesaurus, the standard notation used in its cross reference structure, suggestions for subdividing terms, and the details of coding terms in the 655 field of MARC records. For those interested in purchasing a copy, Genre Terms is in print and available prepaid from ALA Publishing Services (\$5.50 to ACRL members, $\$ 7.50$ to non-members).

Genre Terms will undergo its five-year review by the RBMS Standards Committee in 1988, and a revised edition may be published if the extent of change so warrants. Suggestions for new terms, as well as corrections and alterations to existing terms, scope notes, and references are, therefore, particularly welcome at this time. Any new term proposed should be accompanied by a scope note and references, as appropriate. Please address correspondence to: Chair, Standards Committee, Rare Books and Manuscripts Section, ACRL/ALA, 50 E. Huron St., Chicago, IL 60611, Attn: Genre Terms.

Acrostics

BT Puzzles

Acting editions

BT Plays

Administrative regulations

BT Regulations

Advertisements

RT Advertising mail

Prospectuses

${ }^{*}$ Advertising mail

UF Junk mail

RT Advertisements

Trade catalogues

Anagrams

BT Puzzles

${ }^{*}$ Anti-communist literature

BT Literature of prejudice 
*Anti-homosexual literature

BT Literature of prejudice

Books of hours

UF Hours, Books of

Broadside poems

BT Poems

Broadsides

RT Posters

Catalogues

NT Publishers' catalogues

Ciphers

RT Puzzles

Diaries

NT Overland Journals

Dime novels

BT Novels

${ }^{*}$ Doomsday literature

[Use for works proclaiming the imminent approach of the end of the world.]

Drawing books

[Use for books on how to draw.]

UF Sketchbooks (DELETE)

BT Manuals (Handbooks)

Fabliaux

BT Poems

Fantasy literature

BT Fiction

Fanzines

BT Periodicals

\section{Fiction}

NT Fantasy literature

Film scripts

BT Plays

Grammars

BT Textbooks

Hornbooks

BT Textbooks

Hours, Books of

USE Books of hours

Junk mail

USE Advertising mail

Legislative hearings BT Legislative proceedings

Legislative proceedings NT Legislative hearings

Limericks BT Poems

Literature of prejudice NT Anti-communist literature

Anti-homosexual literature

White supremacist literature

RT Propaganda

Literature of protest

USE Protest literature
Little magazines

BT Periodicals

Manuals (Handbooks)

NT Drawing books

Writing books

${ }^{*}$ Menus

${ }^{*}$ Military histories

NT Regimental histories

Minstrel songs

BT Songs

Musical parts

USE Parts

Novels

NT Dime novels

Penny dreadfuls

Nursery rhymes

BT Poems

Overland journals

BT Diaries

${ }^{*}$ Part books

RT Parts

Parts

UF Musical parts

RT Part books

Pastoral romances

BT Romances

Penny dreadfuls

BT Novels

Periodicals

NT Fanzines

Little magazines

Plays

NT Acting editions

Promptbooks

Poems

UF Verse

NT Broadside poems

Fabliaux

Limericks

Nursery rhymes

Posters

RT Broadsides

Promptbooks

BT Plays

Propaganda

RT Literature of prejudice

Prospectuses

RT Advertisements

${ }^{*}$ Protest literature

UF Literature of protest

NT Student protest literature

${ }^{*}$ Puzzles

NT Acrostics

Anagrams 


\section{WHY NOT \\ CONSIDER A \\ POST-MASTERS \\ PROGRAM?}

The School of Library Service COLUMBIA UNIVERSITY offers the

- DOCTOR OF LIBRARY SCIENCE

- CERTIFICATE IN INFORMATION MANAGEMENT

- CERTIFICATE IN PRESERVATION ADMINISTRATION

- CERTIFICATE IN LIBRARY/ ARCHIVES CONSERVATION

- CERTIFICATE IN ADVANCED

\section{LIBRARIANSHIP}

Founded in 1887, the School of Library Service is the oldest and bestknown graduate program in North America educating librarians and information specialists.

Students may finance studies with fellowship and scholarship grants from the university and other sources, with educational loans, and with part-time or full-time work/study arrangements.

Scholarship awards: for first consideration: deadline: April 1st

Applications for admission to all programs are accepted year-round

School of Library Service

516 Butler Library

Columbia University

New York, NY 10027

(212) 280-2291

Take advantage of the incomparable resources of New York City
RT Ciphers

Rebuses

Riddles

Rebuses

RT Puzzles

Regimental histories

BT Military histories

Regulations

NT Administrative regulations

Riddles

RT Puzzles

Romances

NT Pastoral romances

Sketchbooks (DELETE)

USE Drawing books (DELETE)

Songs

RT Songsters

Songsters

RT Songs

Souvenir programs

[Use for programs distributed to commemorate a specific event, e.g., the dedication of a monument.]

Student protest literature

BT Protest literature

*Survivalist literature

Textbooks

NT Grammars

Hornbooks

Trade catalogues

BT Catalogues

RT Advertising mail

Underground publications

NT Alternative publications

Resistance publications

Verse

USE Poems

${ }^{*}$ White supremacist literature

BT Literature of prejudice

Writing books

BT Manuals (Handbooks)

RBMS Standards Committee members in 1986-87 were: John B. Thomas III (chair), University of Texas at Austin; Dianne Chilmonczyk, Stanford University; Michele Cloonan, University of Illinois GSLIS; Alan Degutis, American Antiquarian Society; Jackie Dooley, University of California, San Diego; Rebecca Hayne, University of California, San Diego; Sara Shatford Layne, University of California, Los Angeles; Hope Mayo, Pierpont Morgan Library; Elisabeth Betz Parker, Library of Congress; and Joe Springer, Mennonite Historical Library, Goshen College. 


\section{Albin receives 1987 Nijhoff Award}

Michael W. Albin, head of the Order Division at the Library of Congress, is the recipient of the Martinus Nijhoff International West European Specialist Study Grant presented by ACRL's Western European Specialists Section. The award, sponsored by Martinus Nijhoff International, consists of two weeks' travel expense for research in Europe.

Albin will be meeting with representatives of $\mathrm{Su}$ rinamese, Iranian and Afghan refugee groups, and agencies that work with them in the Netherlands, the Federal Republic of Germany, and Switzerland, to determine the nature and distribution patterns of their publishing activities. He also will discuss ways in which North American research libraries might collect their publications.

"This is an original project that could well serve as a model for other studies of the many groups of political and economic refugees in our society," said James Campbell, chair of the Martinus Nijhoff Award Committee. The grant was presented during the ALA Annual Conference in San Francisco.

Albin has written numerous publications on the history of the book in the Islamic world and on acquisitions. He is a graduate of the University of Chicago and was for nine years the field director at the Library of Congress office in Cairo.

The Martinus Nijhoff International West European Specialist Study Grant is annually given for an ALA member to visit the Netherlands and to spend ten consecutive working days visiting two other West European countries in order to study some aspect of West European librarianship or bibliography.

Recipients are selected on the basis of the significance and utility of their proposed research as a contribution to the study of the acquisition, organization, or use of library materials relating to Western Europe.

Applications for the 1988 award should be sent to ACRL by December 1, 1987. For more information, contact: Mary Ellen K. Davis, Program Officer, ACRL/ALA, 50 E. Huron St., Chicago, IL 60611 .

\section{Subsidized preservation surveys by NEDCC}

The Northeast Document Conservation Center (NEDCC) will be continuing its subsidized surveys under a grant from the National Endowment for the Humanities. Libraries, archives, museums, record repositories, and historical organizations in New England, New York, and New Jersey with collections of documents, books, photographs, or works of art on paper are invited to apply for a survey.

Preservation planning surveys consist of a oneday site visit by a member of NEDCC's field service team, followed by a detailed report of observations and recommendations. The surveyor will examine building conditions, collections, and storage and handling conditions in order to identify potential hazards to collections, and measures needed to maintain collections in the best condition possible. Specific goals and priorities based on the physical condition of collections will be suggested, and steps needed to implement preservation measures will be outlined.

Surveys provide the basis for long-range preservation planning, including short-, medium-, and long-term goals. For many institutions, such surveys have provided valuable support to funding requests for conservation projects.

The cost of a subsidized survey is $\$ 250$ plus travel expenses, and surveys are awarded competitively. Selections are made periodically, and applications are reconsidered on a regular basis. Since only a limited number of surveys are available, preference is usually given to collections of unique or irreplaceable value, and to institutions who can demonstrate financial need.

The Northeast Document Conservation Center is a non-profit regional conservation center specializing in the treatment of paper and related materials, including documents, books, photographs, and art on paper. Its purpose is to provide the highest quality conservation services, and to serve as an information resource for institutions whose collections include objects made of paper.

Letters of application should be sent to Karen Motylewski, Director of Field Services, NEDCC, 24 School Street, Andover, MA 01810; (617) 4701010. Applications should describe the size and nature of collections; the volume of use; the size and training of the staff; the budget of the organization; and conservation or preservation activities to date.

Surveys continue to be provided at full cost to organizations that cannot demonstrate financial need or cannot wait for the selection process. 


\section{ACRL COMMITTEE VOLUNTEER FORM}

If you are interested in serving on an ACRL standing committee, please complete this form and mail it before December 15, 1987, to: John Tyson, University Librarian, University of Richmond, Richmond, VA 23173.

If you would like to serve on an ACRL section committee, send this form to the appropriate section vicechair/chair-elect before the ALA Midwinter Meeting. You must be a member of the section to be considered for appointment.

NAME, TITLE, INSTITUTIONAL ADDRESS

PREFERRED MAILING ADDRESS

DATE OF APPLICATION

NUMBER OF YEARS AS MEMBER OF ALA ACRL

ACADEMIC BACKGROUND (List institutions, dates of degrees, and relevant subject areas)

PROFESSIONAL ACTIVITIES

ALA or ACRL Committee Assignments

State and Regional Committee Assignments

ALA or ACRL Offices Held

Publications
State and Regional Offices Held

Other

ACRL COMMITTEE PREFERENCES

\section{RELEVANT BACKGROUND OR EXPERIENCE FOR COMMITTEE ASSIGNMENT}

Can you regularly attend the ALA Midwinter and Annual conferences? YES _ NO

(Members of ACRL committees are expected to attend all meetings. Failure to attend two in a row may constitute grounds for removal.)

Please express your major concerns for strengthening the Association of College and Research Libraries on a seperate sheet of paper.

$\square$ If I can't be appointed a full committee member, I would be willing to serve as an intern. 